\title{
Winchite from Mt. Hiei contact aureole, Kyoto, Japan
}

\author{
Takao Hirajima*, Daisuke Nakamura ${ }^{* * *}$ and Katsushi Shirahata ${ }^{* * * *}$ \\ *Department of Geology and Mineralogy, Graduate School of Science \\ Kyoto University, Kyoto 606-8502, Japan \\ **Present address: Department of Earth and Planetary Sciences, \\ Tokyo Institute of Technology, Tokyo, 152-8551, Japan \\ ***Present address: Tohoku Regional Agricultural Administration \\ Office, Sendai, 980-0014, Japan
}

\begin{abstract}
Sodic-calcic amphibole closely associated with aegirine-augite was newly found from a sandy hornfels at Mt. Hiei contact aureole, Kyoto, Japan. The amphibole shows a pleochroism of $\mathrm{X}=$ colorless, $\mathrm{Y}=$ blue and $\mathrm{Z}=$ light blue and is winchite with significant amounts of $\mathrm{TiO}_{2}(1.5-2.5$ wt.\%) and of $\mathrm{Mg}-\mathrm{Fe}-\mathrm{Mn}-\mathrm{Li}$ amphibole component at $\mathrm{B}$ site (ca. 0.1-0.4 cations for $\mathrm{O}=23$ basis). The chemical composition and the coexisting phases of the winchite in this study are similar to those in the alkaline igneous complex.
\end{abstract}

\section{Introduction}

Winchite, one of the end members of the sodic-calcic amphibole (Leake et al., 1997), was originally found from Kajlidongri mine, Madhya Pradesh, India, in the beginning of the 20th century (see Nayak and Leake, 1975). Since then, this mineral has been reported from various geological settings, such as a) metamorphosed Mn-ore deposits (e.g., Bilgrami, 1955: Nambu et al., 1980), b) high-pressure metamorphic rocks (e.g., Maresch et al., 1982: Smelik and Veblen, 1989: Otsuki and Banno, 1990) and c) alkaline igneous complex (e.g., Strong and Taylor, 1984). The present study reports a new occurrence of winchite closely associated with aegirine-augite in a sandy hornfels from Mt. Hiei contact aureole, Kyoto, Japan. In this contribution, the mode of occurrence and chemical character of the winchite will be described and its petrological significance will be briefly discussed.

T. Hirajima, 平島崇男, hirajima @ pet.kueps.kyoto-u.ac.jp Corresponding author

D. Nakamura，中村大輔，daisuke@ geo.titech.ac.jp

K. Shirahata, 白旗克志, katsushi_shirahata@ tohoku.maff.go.jp

\section{Geological outline}

The winchite was found in a sandy hornfels from the western slope of Mt. Mizui, which occupies the northern part of the Hiei Mountains bounded by two active faults with NNE-SSW trend, i.e., Hanaore Fault and Hiei Fault (Fig. 1). The main constituent of the Hiei Mountains is the Jurassic accretionary sediment of the Tamba Group and late Cretaceous granitoids. The granitoids in this area are subdivided into Ohgi tonalite and Hiei granite with radiometric ages ranging from 73 to $99 \mathrm{Ma}$ (Hayase and Ishizaka, 1967: Kawano and Ueda, 1966: Sawada and Itaya, 1993). The major mafic phases in the granitoids are hornblende and biotite. Clinopyroxene is rarely recognized in the Ohgi tonalite (Kimura et al., 1998).

The intrusion of the late Cretaceous granitoids caused contact metamorphism to the surrounding sediments of the Tamba Group. The three mineral zones, i.e., cordierite, biotite and chlorite zones with descending order of the metamorphism, were established in the southern margin of the contact aureole of the Hiei granite. The metamorphic zoning was defined by the appearance of index minerals in metapelite and by the graphitization degree of carbonaceous materials by Nakamura (1995).

The recent petrological study in the Hiei Mountains by our group reveals that the muddy hornfels of the 


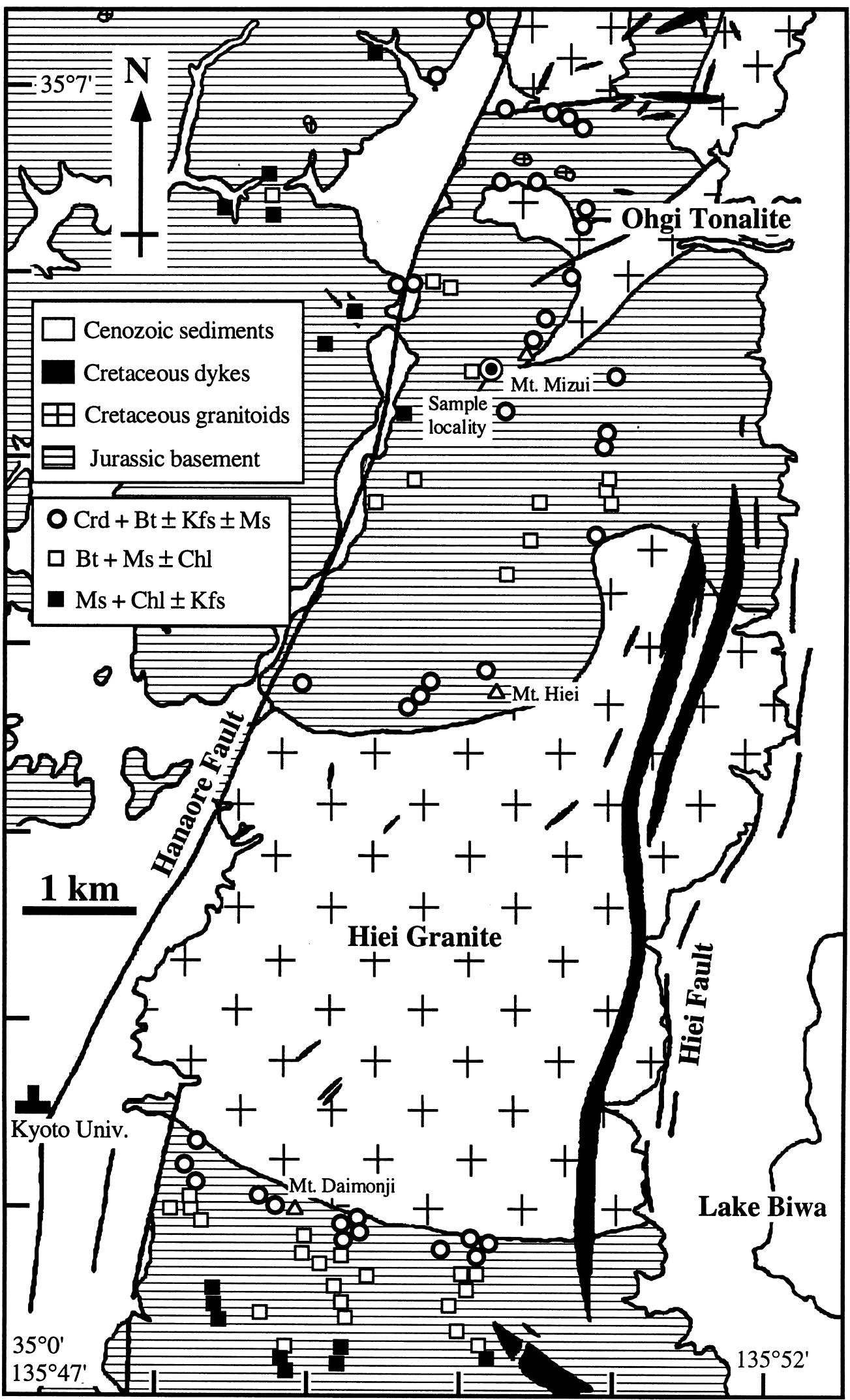

Figure 1. Geologic map with the locality of index metamorphic minerals around Mt. Hiei contact aureole. Lithologic distribution mainly follows Kimura et al. (1998). Metamorphic zoning to the south of the Hiei granite quotes Nakamura (1995). Crd, cordierite; Bt, biotite; Kfs, K-feldspar; Ms, muscovite; Chl, chlorite. 
Tamba Group located between Hiei granite and Ohgi tonalite contains cordierite and/or biotite. This fact suggests that the Tamba Group in the relevant area suffered the cordierite or biotite grade contact metamorphism (Fig. 1).

The sandy hornfels with winchite was found in the western slope of Mt. Mizui, about $500 \mathrm{~m}$ above sea level. As far as we observed more than 200 thin sections of muddy and sandy hornfels in the Hiei Mountains, winchite was not found from the other studied specimens. The sandy hornfels with winchite is intercalated with muddy hornfels, which contains tiny and abundant biotite. Although cordierite was not found from this locality, the outcrop of the winchite-bearing sandy hornfels is located near the cordierite-in isograd (Fig. 1). This suggests that the rock was heated to temperatures slightly less than $510^{\circ} \mathrm{C}$ at 2-2.3 kbar (Nakamura, 1995). Another remarkable feature in this outcrop is the development of quartz or quartz-feldspathic veins in the hornfels. A quartz-feldspathic vein contains amphiboles with high-alkali and $\mathrm{Ti}$ contents $\left(\mathrm{Na}_{2} \mathrm{O}+\right.$ $\mathrm{K}_{2} \mathrm{O}=5.6-7.1$ wt.\% and $\mathrm{TiO}_{2}=3.5-4.8$ wt.\%, Okamoto, 1999).

\section{Petrography and chemical composition}

The sandy hornfels is mainly composed of detrital grains of quartz, K-feldspar and plagioclase with ca. $1 \mathrm{~mm}$ diameter in average. Along their grain boundaries, thermal metamorphic minerals (up to $0.3 \mathrm{~mm}$ in diameter) are well developed (Fig. 2). The main metamorphic minerals are biotite, muscovite, blue amphibole and green clinopyroxene. Subordinate amounts of titanite, monazite, zircon and opaque minerals are also observed.

Both the blue amphibole and the green clinopyroxene occur as small prismatic crystals $0.05-0.30 \mathrm{~mm}$ in length (Fig. 2). The blue amphibole shows a pleochroism of $\mathrm{X}=$ colorless, $\mathrm{Y}=$ blue, and $\mathrm{Z}=$ light blue.

Chemical analyses of the blue amphibole and the green clinopyroxene were performed by an electron microprobe (Hitachi S-550) with Kevex energy dispersion system (Quantum detector) at Kyoto University. The procedure follows that of Mori and Kanehira (1984) and Hirajima and Banno (1991). Table 1 shows representative chemical analyses of amphibole and clinopyroxene. The nomenclature of amphibole follows Leake et al. (1997).

\section{Amphibole}

The amphibole is homogeneous in each grain but slightly changes its composition from a grain to another.
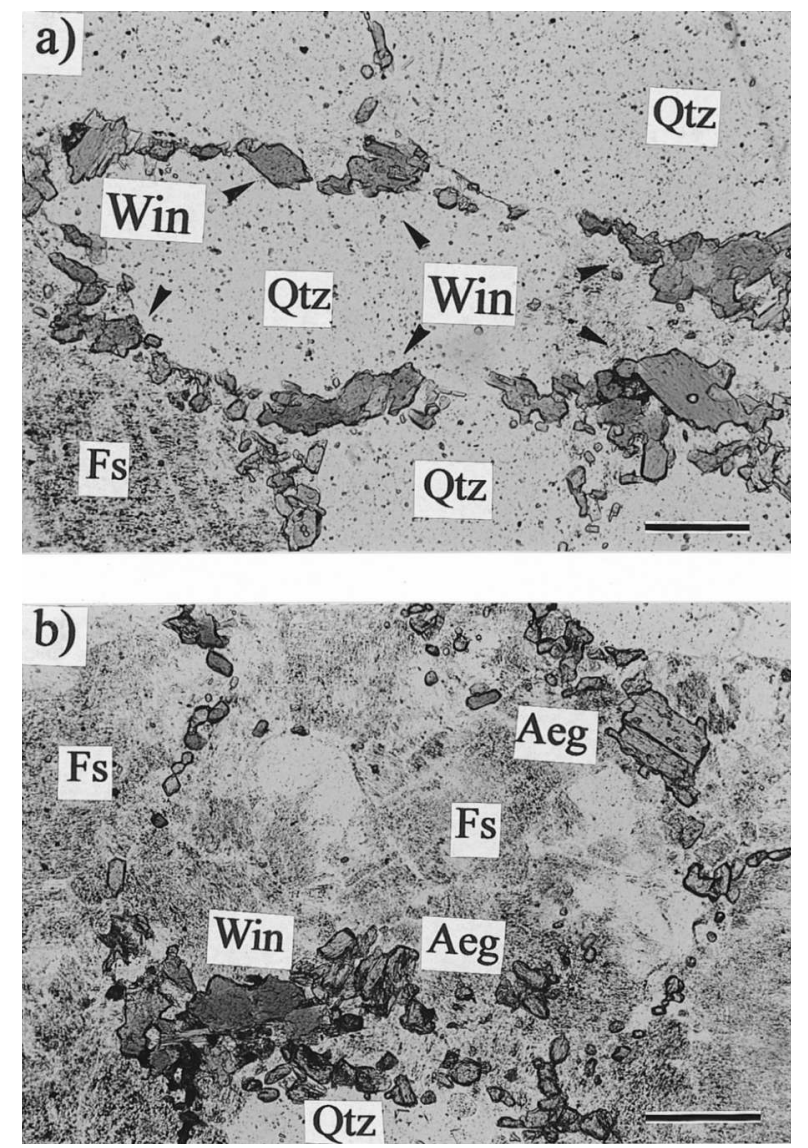

Figure 2. (a) Photomicrograph of winchite (Win) developing along the grain boundary of quartz (Qtz) and feldspar (Fs) grains. Scale bar is $0.1 \mathrm{~mm}$. Opened Nicol. (b) Photomicrograph of winchite (Win) and aegirie-augite (Aeg) developing along the grain boundary of quartz (Qtz) and feldspar (Fs) grains. Scale bar is $0.1 \mathrm{~mm}$. Opened Nicol.

Because the amphibole is closely associated with aegirine-augite, we need to estimate $\mathrm{Fe}^{3+}$ content in the amphibole. There is no explicit way of the $\mathrm{Fe}^{3+} / \mathrm{Fe}^{2+}$ ratio estimation for amphiboles formed in the lowpressure conditions. We tentatively adopted a charge balance method following Leake et al. (1997). In Table 1, two chemical formulae (1: all iron as $\mathrm{FeO}$ and 2: averaging the minimum and maximum ferric estimation or normalizing $\mathrm{Si}$ as 8.0 by Leake et al. (1997), see their Appendix 2: Table 2) are shown for comparison. Microprobe data of the amphibole are summarized as follows: a) the tetrahedral site is mainly occupied by $\mathrm{Si}$, b) the sum of $\mathrm{Ca}$ and $\mathrm{Na}$ in $\mathrm{B}$ site is larger than 1.5 and less than 1.7 , c) $\mathrm{Ca} / \mathrm{Na}$ ratio in $\mathrm{B}$ site is almost 1 , and d) the sum of $\mathrm{Na}$ and $\mathrm{K}$ in $\mathrm{A}$ site is less than 0.2, suggesting that the analyzed amphibole is winchite. The winchite contains a significant amount of $\mathrm{TiO}_{2}$ (1.5-2.5 wt.\%). On the behavior of $\mathrm{Ti}$ in amphibole, following ideas are proposed by many workers: $\mathrm{Ti}^{4+}$ coordinates in A) tetrahedral site (e.g., Della Ventura et 
Table 1. EPMA data of blue amphibole and green clinopyroxene in sandy hornfels (MS14)

\begin{tabular}{|c|c|c|c|c|c|c|c|c|c|}
\hline \multicolumn{7}{|c|}{ Amphibole } & \multicolumn{3}{|c|}{ Clinopyroxene } \\
\hline \multicolumn{2}{|c|}{ winchite 1} & \multicolumn{2}{|r|}{ winchite 2} & \multicolumn{2}{|c|}{ winchite 3} & & \multicolumn{2}{|c|}{ pyroxene 1} & \\
\hline$\overline{\mathrm{SiO}_{2}}$ & 53.06 & & 53.94 & & 55.11 & & $\overline{\mathrm{SiO}_{2}}$ & 54.64 & \\
\hline $\mathrm{TiO}_{2}$ & 1.52 & & 1.61 & & 2.16 & & $\mathrm{TiO}_{2}$ & 0.47 & \\
\hline $\mathrm{Al}_{2} \mathrm{O}_{3}$ & 0.85 & & 1.08 & & 0.75 & & $\mathrm{Al}_{2} \mathrm{O}_{3}$ & 0.19 & \\
\hline $\mathrm{FeO}^{*}$ & 19.63 & & 19.09 & & 17.85 & & $\mathrm{FeO}^{*}$ & 18.12 & \\
\hline $\mathrm{MnO}$ & 0.31 & & 0.21 & & 0.52 & & $\mathrm{MnO}$ & 0.37 & \\
\hline $\mathrm{MgO}$ & 11.2 & & 11.72 & & 11.31 & & $\mathrm{MgO}$ & 7.49 & \\
\hline $\mathrm{CaO}$ & 4.87 & & 4.98 & & 4.83 & & $\mathrm{CaO}$ & 14.52 & \\
\hline $\mathrm{Na}_{2} \mathrm{O}$ & 2.98 & & 3.18 & & 2.86 & & $\mathrm{Na}_{2} \mathrm{O}$ & 4.60 & \\
\hline $\mathrm{K}_{2} \mathrm{O}$ & 0.45 & & 0.46 & & 0.40 & & $\mathrm{~K}_{2} \mathrm{O}$ & 0.00 & \\
\hline Total & 94.87 & & 96.27 & & 95.79 & & Total & 100.40 & \\
\hline \multirow[t]{2}{*}{$\overline{\mathrm{O}}$} & 23 & & 23 & & 23 & & $\overline{\mathrm{O}}$ & 6 & \\
\hline & All $\mathrm{Fe}^{2+}$ & Ave* & All $\mathrm{Fe}^{2+}$ & Ave* & All Fe $\mathrm{Fe}^{2+}$ & $\mathrm{Si}=8.0$ & & All $\mathrm{Fe}^{2+}$ & Cation $=4.0$ \\
\hline $\mathrm{Si}$ & 8.046 & 7.996 & 8.028 & 7.984 & 8.150 & 8.000 & $\mathrm{Si}$ & 2.089 & 2.056 \\
\hline $\mathrm{Al}^{(\mathrm{IV})}$ & 0.000 & 0.004 & 0.000 & 0.016 & 0.000 & 0.000 & $\mathrm{Al}^{(\mathrm{IV})}$ & 0.000 & 0.000 \\
\hline Sum & 8.046 & 8.000 & 8.028 & 8.000 & 8.150 & 8.000 & Sum & 2.089 & 2.056 \\
\hline $\mathrm{Al}^{(\mathrm{VI})}$ & 0.152 & 0.147 & 0.189 & 0.173 & 0.104 & 0.128 & $\mathrm{Al}^{(\mathrm{VI})}$ & 0.009 & 0.008 \\
\hline $\mathrm{Ti}$ & 0.173 & 0.172 & 0.180 & 0.179 & 0.207 & 0.236 & $\mathrm{Ti}$ & 0.014 & 0.013 \\
\hline $\mathrm{Fe}^{3+}$ & & 0.283 & & 0.251 & & 0.933 & $\mathrm{Fe}^{3+}$ & & 0.189 \\
\hline $\mathrm{Mg}$ & 2.532 & 2.516 & 2.600 & 2.586 & 2.562 & 2.448 & $\mathrm{Mg}$ & 0.417 & 0.420 \\
\hline $\mathrm{Fe}^{2+}$ & 2.143 & 1.881 & 2.030 & 1.811 & 2.127 & 1.255 & $\mathrm{Fe}^{2+}$ & 0.560 & 0.370 \\
\hline Sum & 5.000 & 5.000 & 5.000 & 5.000 & 5.000 & 5.000 & Sum & 1.000 & 1.000 \\
\hline $\mathrm{Fe}^{2+}$ & 0.346 & 0.310 & 0.346 & 0.301 & 0.103 & 0.000 & $\mathrm{Fe}^{2+}$ & 0.019 & 0.011 \\
\hline $\mathrm{Mn}$ & 0.040 & 0.040 & 0.026 & 0.026 & 0.060 & 0.064 & $\mathrm{Mn}$ & 0.012 & 0.012 \\
\hline $\mathrm{Ca}$ & 0.791 & 0.786 & 0.794 & 0.790 & 0.731 & 0.751 & $\mathrm{Ca}$ & 0.595 & 0.585 \\
\hline $\mathrm{Na}$ & 0.823 & 0.864 & 0.833 & 0.883 & 0.979 & 0.805 & $\mathrm{Na}$ & 0.341 & 0.336 \\
\hline Sum & 2.000 & 2.000 & 2.000 & 2.000 & 1.873 & 1.620 & Sum & 0.967 & 0.944 \\
\hline $\mathrm{Na}$ & 0.054 & 0.007 & 0.084 & 0.030 & 0.000 & 0.000 & & & \\
\hline $\mathrm{K}$ & 0.087 & 0.087 & 0.087 & 0.087 & 0.117 & 0.074 & & & \\
\hline Sum & 0.141 & 0.093 & 0.172 & 0.117 & 0.117 & 0.074 & & & \\
\hline Total & 15.186 & 15.093 & 15.200 & 15.117 & 15.139 & 14.694 & Total & 4.064 & 4.000 \\
\hline
\end{tabular}

Ave*: average ferric estimaiton follows Leake et al. (1997).

$\mathrm{Si}=8.0$ : ferric estimation for normalizing $\mathrm{Si}=8.0$ follows Leake et al. (1997)

al., 1991) and B) octahedral site (e.g., Kitamura et al., 1975; Hawthorne et al., 1998). As the studied amphiboles show $\mathrm{Si} \approx 8.00$ for $\mathrm{O}=23$, Ti may occupy the octahedral site in them. The other common character for the studied amphiboles is that significant amounts of $\mathrm{Mg}-\mathrm{Fe}-\mathrm{Mn}-\mathrm{Li}$ amphibole component (0.1-0.4 cations for $\mathrm{O}=23$ ) occupy $\mathrm{B}$ site. Some winchite (e.g., winchite 3 in Table 3) is in shortage of total cations in B site. The incorporation of $\mathrm{Li}$ in the studied amphibole is one of the explanations for the shortage of total cations in B site.

\section{Clinopyroxene}

Green clinopyroxene is also homogeneous in each grain but slightly changes its composition from a grain to another. It is aegirine-augite with acmite content $(=(\mathrm{Na}-\mathrm{Al}) /(\mathrm{Ca}+\mathrm{Na}))$ from 0.25 to 0.30 and is almost free from jadeite component $(=\mathrm{Al} /(\mathrm{Ca}+\mathrm{Na})<0.01)$ (Table 1).

\section{Discussion}

\section{Characteristic features of winchite according to their mode of occurrences}

Some blue or bluish-green amphiboles (e.g., glaucophane, crossite and barroisite) are one of the diagnostic minerals for the high-pressure and low-temperature (HP/LT) metamorphism. However, other blue am- 
phiboles (e.g., riebeckite and winchite) occur in alkaline igneous rocks, metamorphosed $\mathrm{Mn}$-ore deposits and authigenic environments as well as in the HP/LT metamorphic rocks.

The chemistry of winchite reflects both the $\mathrm{P}-\mathrm{T}$ conditions of its formation and the host rock compositions as follows. Winchites in the HP/LT metamorphic rocks are generally free from $\mathrm{TiO}_{2}$ (e.g., in basic schists of the Sanbagawa belt by Higashino et al., 1982; in blueschist of Vermont, Smelik and Veblen, 1989; in eclogite of Venezuela, Maresch et al., 1982, and of Spitsbergen, Hirajima et al., 1988) and they contain significant amounts of $\mathrm{Al}_{2} \mathrm{O}_{3}$ (e.g., 1.5-4.5 wt.\% in the Sanbagawa belt and 7.0-8.0 wt.\% in Venezuela and Spitsbergen) as a glaucophane component. Winchite from $\mathrm{Mn}$-ore deposits is characterized by a high content of MnO (ca. 2.0-15.4 wt.\%, e.g., Nambu et al., 1980) and is closely associated with other Mn-rich phases, such as manganocummingtonite (former tirodite), judite, braunite etc. (Bilgrami, 1955: Nayak and Leake, 1975). Winchite from alkaline igneous rocks is characterized by high $\mathrm{TiO}_{2}$ (e.g., 0.3-1.6 wt.\%) and low $\mathrm{Al}_{2} \mathrm{O}_{3}$ (e.g., 0.71.3 wt.\%) and is closely associated with aegirine/aegirine-augite, $\mathrm{K}$-feldspar and plagioclase (Strong and Taylor, 1984). The chemical composition of the winchite in this study $\left(\mathrm{TiO}_{2}=1.5-2.3\right.$ wt.\% and $\mathrm{Al}_{2} \mathrm{O}_{3}=0.6^{-}$ $1.1 \mathrm{wt. \% )}$ and its associated minerals are very similar to those in the alkaline igneous complex.

\section{Why winchite developed in sandy hornfels ?}

What is the main reason for the development of winchite and aegirine-augite in the sandy hornfels? If the studied rock originally had a peculiar chemical composition with high-Na, $\mathrm{Fe}^{3+}$ and $\mathrm{Ti}$ contents rather than the common composition of sandstone in the Tamba Group, the formation of winchite and aegirine-augite should be expected in the biotite or cordierite grade contact metamorphism.

Strong and Taylor (1984) pointed out that the fluid chemistry is also important in controlling the chemical characteristics of amphiboles in per-alkaline intrusive and volcanic rocks, along with host-rock compositions. Czamanske and Atkin (1985) reported the metasomatic origin of acmite and sodic amphiboles with unusual $\mathrm{Ti}$ content in lithic-wacke inclusions within the alkalic ultramafic diatreme. The development of quartz and quartz-feldspathic veins is an evidence of igneous activity at the outcrop of the studied rock. Many thin veins $(<1-2 \mathrm{~mm}$ in width) radiate from the quartz-feldspathic vein (a few $\mathrm{cm}$ in width) with the high-alkali and $\mathrm{Ti}$ amphibole. Therefore, another possible cause for the formation of winchite and aegirine-augite in the present study is the enrichment of $\mathrm{Na}, \mathrm{Fe}^{3+}$ and $\mathrm{Ti}$ by a vein forming fluid

\section{Acknowledgments}

This study compiles a part of the results obtained by the area study "The development of Higashiyama-Sankei", represented by Prof. M. Kitamura, Kyoto University. We express sincere thanks to Kyoto City for the financial support and to Profs. S. Arai, and M. Enami, Dr. A. Miyake and Miss Naoko Matsumoto for critical and constructive comments.

\section{References}

Bilgrami, S.A. (1955) Manganese amphiboles from Chikla, Bhandara district, India. Mineralogical Magazine, 30, 633-644.

Czamanske, G.K. and Atkin, S.A. (1985) Metasomatism, titanian acmite, and alkali amphiboles in lithic-wacke inclusions within the Coyote Peak diatreme, Humboldt County, California. American Mineralogist, 70, 499-516.

Della Ventura, G., Robert, J.-L. and Beny, J.-M. (1991) Tertrahedrally coordinated $\mathrm{Ti}^{4+}$ in synthetic Ti-rich potassic richterite: evidence from XRD, FTIR and Raman studies. American Mineralogist, 76, 1134-1140.

Hawthorne, F.C., Oberti, R. and Zanetti, A. (1998) The role of Ti in hydrogen-deficient amphiboles: sodic-calcic and sodic amphiboles from Coyote Peak, California. The Canadian Mineralogist, 36, 1253-1265.

Hayase, I. and Ishizaka, K. (1967) Rb-Sr dating on the rocks in Japan (I), South western Japan. The Journal of Japanese Association of Mineralogists, Petrologists and Economic Geologists, 58, 202-212. (in Japanese with English abstract)

Higashino, T., Sakai, C., Otuki, M. and Itaya, T. (1982) Electron microprobe analyses of rock-forming minerals from the Sanbagawa metamorphic rocks, Shikoku Part I. Asemi River area. The Science Reports of Kanazawa University, 26, 73-122.

Hirajima, T. and Banno, S. (1991) Electron-microprobe analysis of rock forming minerals with Kevex-delta IV (Quantum detector). Hitachi Scientific Instrument News, 34, 1118-1134. (in Japanese with English abstract)

Hirajima, T., Banno, S., Hiroi, Y., and Ohta, Y. (1988) Phase petrology of eclogites and related rocks from the Motalafjella high-pressure metamorphic complex in Spitsbergen and its significance. Lithos, 22, 75-97.

Kawano, Y. and Ueda, Y. (1966) K-Ar dating on the igneous rocks in Japan, Granitic rocks in southwestern Japan. The Journal of Japanese Association of Mineralogists, Petrologists and Economic Geologists, 56, 191-211. (in Japanese with English abstract)

Kimura, K., Yoshioka, T., Imoto, N., Tanaka, S., Musashino, M. and Takahashi, Y. (1998) Geology of the KyotoTohokubu district. With geological Sheet Map at 1: 50,000 , Geological Survey of Japan, pp. 89. (in Japanese with English abstract) 
Kitamura, M., Tokonami, M. and Morimoto, N. (1975) Distribution of titanium atoms in oxy-kaersutite. Contributions to Mineralogy and Petrology, 51, 167-172.

Leake, B.E., Woolley, A.R., Arps, C.E.S., Birch, W.D., Gilbert, M.C., Grice, J.D., Hawthorne, F.C., Kato, A., Kisch, H.J., Krivovichev, V.G., Linthout, K., Laird, J., Mandarino, J.A., Maresch, W.V., Nickel, E.H., Rock, N.M.S., Schumacher, J.C., Smith, D.C., Stephenson, N.C.N., Ungaretti, L., Whittaker, E.W.J. and Youzhi, G. (1997) Nomenclature of amphiboles: Report of the subcommittee on Amphiboles of the International Mineralogical Association, Commission on New Minerals and Mineral Names. American Mineralogist, 82, 1019-1037.

Maresch, W.V, Medenbach, O. and Rudolph, A. (1982) Winchite and the actinolite-glaucophane miscibility gap. Nature, 296, 731-732.

Mori, T. and Kanehira, K. (1984) X-ray energy spectrometry for electron-probe analysis. The Journal of the Geological Society of Japan, 90, 271-285.

Nakamura, D. (1995) Comparison and interpretation of graphitization in contact and regional metamorphic rocks. The Island Arc, 4, 112-127.

Nambu, M., Tanida, K. and Kitamura, T. (1980) Chemical composition of manganese bearing amphibole from Japan and its classification. The Journal of Japanese Association of Mineralogists, Petrologists and Economic Geologists, 14, 98-116. (in Japanese with English abstract)
Nayak, V.K. and Leake, B.E. (1975) On "winchite" from the original locality at Kajlidongri, India. Mineralogical Magazine, 40, 395-399.

Okamoto, J. (1999) Amphiboles from Mt. Hiei contact aureole. Graduation thesis of Kyoto University, pp. 46, MS. (in Japanese)

Otsuki, M. and Banno, S. (1990) Prograde and retrograde metamorphism of hematite-bearing basic schists in the Sanbagawa belt in central Shikoku. Journal of metamorphic Geology, 8, 425-439.

Sawada, Y. and Itaya, T. (1993) K-Ar ages of a Late Cretaceous granitic ring complex around southern Lake Biwa, Southwest Japan -Cooling history of a huge cauldron. The Journal of the Geological Society of Japan, 99, 975-990. (in Japanese with English abstract)

Smelik, E.A. and Veblen, D.R. (1989) A five-amphibole assemblage from blueschists in northern Vermont. American Mineralogist, 74, 960-964.

Strong, D.F. and Taylor, R.P. (1984) Magmatic-subsolidus and oxidation trends in composition of amphiboles from silica-saturated peralkaline igneous rocks. Tschermaks Mineralogische und Petrographische Mitteilungen., 32, 211-222.

Manuscript received ; 9 June, 2000

Manuscript accepted ; 11 August, 2000 